Article

\title{
Effect of Formwork Removal Time Reduction on Construction Productivity Improvement by Mix Design of Early Strength Concrete
}

\author{
Taegyu Lee ${ }^{1,+} \mathbb{C}$, Jaehyun Lee ${ }^{2,+}$, Jinsung Kim ${ }^{3}$, Hyeonggil Choi ${ }^{3, *}$ and Dong-Eun Lee ${ }^{3} \mathbb{C}$ \\ 1 Department of Fire and Disaster Prevention, Semyung University, 65 Semyung-ro, Jecheon-si, \\ Chungbuk 27136, Korea; ltg777@semyung.ac.kr \\ 2 Department of Safety Engineering, Seoul National University of Science and Technology, 232 Gongneung-ro, \\ Nowon-gu, Seoul 01811, Korea; archi0528@seoultech.ac.kr \\ 3 School of Architecture, Civil, Environment, and Energy Engineering, Kyungpook National University, \\ 80 Daehakro, Bukgu, Daegu 41566, Korea; kjs07406@knu.ac.kr (J.K.); dolee@knu.ac.kr (D.-E.L.) \\ * Correspondence: hgchoi@knu.ac.kr; Tel.: +82-53-950-5596 \\ + These authors contributed equally to this work.
}

Received: 4 September 2020; Accepted: 6 October 2020; Published: 11 October 2020

\begin{abstract}
In this study, we examined the effects of cement fineness, $\mathrm{SO}_{3}$ content, an accelerating agent, and chemical admixtures mixed with unit weights of cement on concrete early strength using concrete mixtures. C24 (characteristic value of concrete, $24 \mathrm{MPa}$ ) was used in the experiment conducted. Ordinary Portland cement (OPC), high fineness and $\mathrm{SO}_{3} \mathrm{OPC}$ (HFS_OPC), and Early Portland cement (EPC) were selected as the study materials. The unit weights of cement were set to OPC 330, 350, and 380. Further, a concrete mixture was prepared with a triethanolamine (TEA)-based chemical admixture to HFS. A raw material analysis was conducted, and the compressive strength, temperature history, and maturity (D.h) were examined. Then, the vertical formwork removal time was evaluated according to the criterion of each country. Finally, the time required to develop concrete strength of $5 \mathrm{MPa}$ was estimated. Results showed that the early strength of concrete mixed with HFS and EPC was greater than that exhibited by concrete with an increased unit weight of cement with OPC. In addition, when HFS was used with EPC, its strength developed early, similar to the trend exhibited by EPC, even at low temperatures.
\end{abstract}

Keywords: early strength of concrete; cement fineness; $\mathrm{SO}_{3}$ content; accelerating agent; maturity; Ordinary Portland cement

\section{Introduction}

Early strength concrete is used as an elemental technology for reducing construction time by realizing early formwork removal at construction sites [1,2]. Early strength concrete can be investigated via two methods: (1) Appropriate management of the proportions of materials mixed in the concrete, and (2) acceleration of cement hydration by varying the curing temperature [3,4]. It is possible to decrease the setting time of concrete and increase the curing speed by reducing the water to cement (W/C) [5]. For mixtures used in the field, a reduction in the W/C ratio increases the design strength by increasing the unit weight of cement. This method can improve the strength of concrete in a certain range when applied to the mixture design of a site. However, the method does not consider economic efficiency and cannot be used to improve concrete mixture design [6].

Ordinary Portland cement (OPC) is commonly used in concrete mixtures owing to its chemical stability. However, it exhibits limitations in terms of developing early strength in concrete [7]. Early strength in concrete can be developed using early strength cement, which increases the $\mathrm{C}_{3} \mathrm{~S}$ content and 
fineness and decreases the $\mathrm{C}_{2} \mathrm{~S}$ content; thus, for early strength development, early strength cement is better than OPC [8]. Despite the excellent early strength development, the early strength cement has not been commonly used because it is difficult to develop a stable long-term strength, hence reducing the economic efficiency.

Bentz et al. [9-13] reported that a higher W/C ratio may have a greater influence on the early strength development and cement with a higher fineness can reduce the formwork removal time under the curing conditions at actual construction sites.

It is possible to develop the early strength of cement for which the fineness of OPC is increased to $380 \mathrm{~m}^{2} / \mathrm{kg}$, and the $\mathrm{SO}_{3}$ content is increased to $3.1 \%$ in the scope of the $13-20{ }^{\circ} \mathrm{C}$ temperature range $[14,15]$. Rixon et al. [16-18] conducted research on the early strength development of OPC by reducing the setting time using triethanolamine (TEA). Further, according to the research results reported by Aggoun et al. [19], rapid curing occurred when the TEA accelerating agent was used in large quantities. A retarder was also used to control the rapid curing. However, the chemical decomposition of the accelerating agent and retarder was also reported in some cases. These studies have low reproducibility for the actual production of concrete, and they also have limitations in determining economical mixtures by fully considering the climate conditions of local areas. In particular, when the temperature of a local area is irregular and the curing temperature is less than $15^{\circ} \mathrm{C}$, accurate strength prediction for determining the formwork removal time [20-24] is difficult.

In this study, we examined the influence of unit weight of cement in concrete that uses OPC on early strength development by considering the conditions of construction sites and referring to the concrete mixture of $\mathrm{C} 24$ (characteristic value of concrete, $24 \mathrm{MPa}$ ). In addition, high fineness and $\mathrm{SO}_{3}$ OPC (HFS_OPC) and early Portland cement (EPC) were selected, for which the fineness and $\mathrm{SO}_{3}$ content were varied considering the economic efficiency of mixture design. Further, the effect of the addition of a polycarboxylic (PC) superplasticizer mixed with an accelerating agent on the acceleration of early strength was analyzed. This study aims to examine the influencing factors of cement for early strength development by curing temperature and to develop the optimal mixture with economic efficiency. In addition, the formwork removal time was predicted, and its influence on the construction productivity was examined.

In conclusion, this study aims to contribute toward enhancing the utilization of construction sites by investigating the effects of various concrete material factors, amount of cement, type of cement, chemical admixture, and $\mathrm{SO}_{3}$ on the early strength.

\section{Materials and Methods}

\subsection{Materials}

Table 1 summarizes the chemical composition of the binders by X-ray fluorescence (XRF) analysis. OPC (ASTM type I), HFS_OPC, and EPC (ASTM type III) were used as the concrete binders. For OPC, the density and fineness were $3150 \mathrm{~kg} / \mathrm{m}^{3}$ and $330 \mathrm{~m}^{2} / \mathrm{kg}$; for HFS, they were $3130 \mathrm{~kg} / \mathrm{m}^{3}$ and 380 $\mathrm{m}^{2} / \mathrm{kg}$; and for EPC, they were $3160 \mathrm{~kg} / \mathrm{m}^{3}$ and $488 \mathrm{~m}^{2} / \mathrm{kg}$, respectively.

Table 1. Chemical composition of the used binders by X-ray fluorescence (XRF) analysis.

\begin{tabular}{|c|c|c|c|c|c|c|c|c|c|}
\hline \multirow{2}{*}{ Materials } & \multicolumn{8}{|c|}{ Chemical Composition (\%) } & \multirow{2}{*}{ L.O.I. ${ }^{(4)}$} \\
\hline & $\mathrm{CaO}$ & $\mathrm{Al}_{2} \mathrm{O}_{3}$ & $\mathrm{SiO}_{2}$ & $\mathrm{MgO}$ & $\mathrm{Fe}_{2} \mathrm{O}_{3}$ & $\mathrm{SO}_{3}$ & $\mathrm{~K}_{2} \mathrm{O}$ & Others & \\
\hline $\mathrm{OPC}^{(1)}$ & 60.34 & 4.85 & 19.82 & 3.83 & 3.30 & 2.90 & 1.08 & 0.86 & 3.02 \\
\hline HFS ${ }^{(2)}$ & 61.00 & 4.51 & 19.22 & 4.14 & 3.35 & 3.13 & 1.04 & 0.79 & 2.82 \\
\hline $\mathrm{EPC}^{(3)}$ & 61.44 & 4.72 & 20.33 & 2.95 & 3.42 & 3.73 & 0.95 & 0.79 & 1.67 \\
\hline
\end{tabular}


Figure 1 shows the results of the sieve analysis curves on the aggregates. Washed sea sand and crushed sand were used as the fine aggregates. Further, the fineness modulus of the fine aggregates was 2.84 .

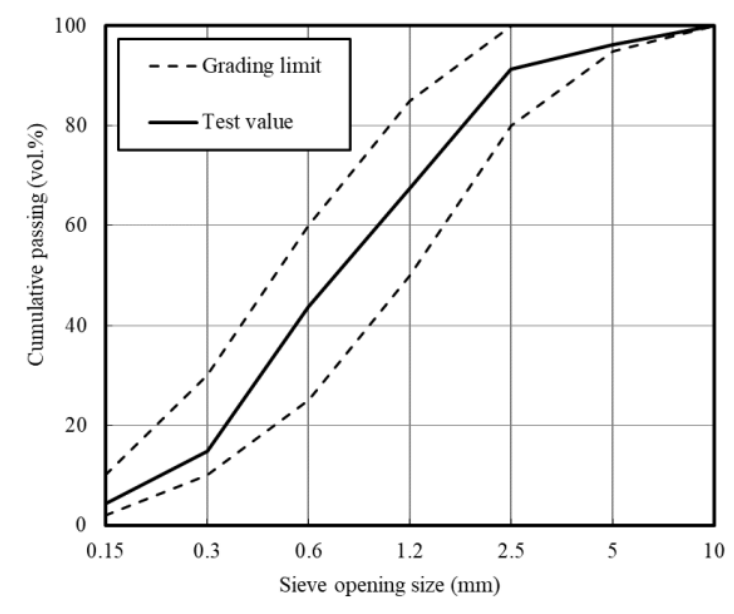

(a)

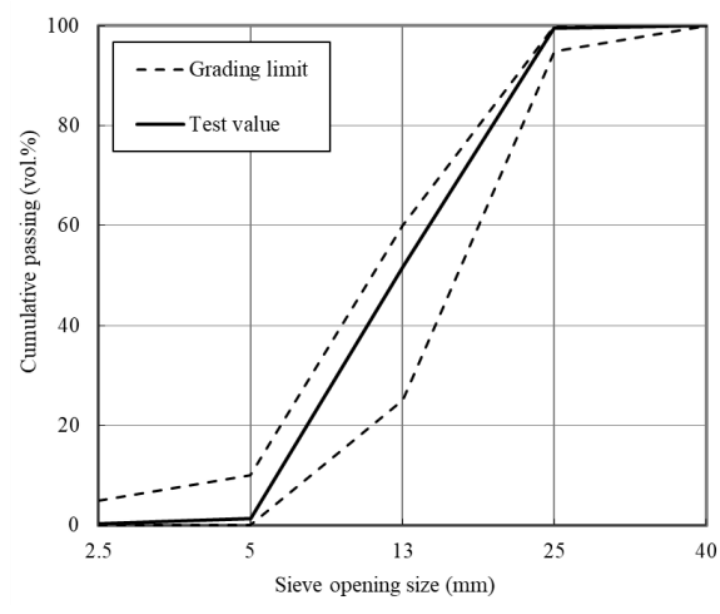

(b)

Figure 1. Gradation sieve analysis test result for the aggregates: (a) Fine aggregates and (b) coarse aggregates.

For washed sea sand, the fineness, density, and absorption were $2.01,2600 \mathrm{~kg} / \mathrm{m}^{3}$, and $0.79 \%$, respectively. For crushed sand, the fineness, absorption, and density were $3.29,0.87 \%$, and $2570 \mathrm{~kg} / \mathrm{m}^{3}$, respectively. Crushed coarse aggregate with a size of $25 \mathrm{~mm}$, absorption of $0.76 \%$, and density of $2600 \mathrm{~kg} / \mathrm{m}^{3}$ was used as the coarse aggregate. For the chemical admixture, a PC superplasticizer and a TEA-based PC superplasticizer were used.

\subsection{Experimental Plan and Mix Proportions}

Table 2 shows the experimental plan. For the concrete strength, the concrete of $\mathrm{C} 24$ was referenced, which is most commonly used at construction sites. For C24 (330 P) that used OPC, the W/C was set to 0.50 and the unit weight of cement was set to $330 \mathrm{~kg} / \mathrm{m}^{2}$. In general, the unit weight of cement is increased to secure the early strength of concrete at construction sites. In this study, C27 (characteristic value of concrete $=27 \mathrm{MPa}$ ) and C30 (characteristic value of concrete $=30 \mathrm{MPa}$ ) were selected, which increased the unit weight of cement. The unit weight of cement of C27 (350P) and C30 (380P) was 350 and $380 \mathrm{~kg} / \mathrm{m}^{2}$, respectively.

Table 2. Experimental plan.

\begin{tabular}{|c|c|c|c|c|c|c|c|}
\hline Series & $\begin{array}{l}\text { Mix } \\
\text { ID. }\end{array}$ & $\mathrm{W} / \mathrm{C}$ & $\begin{array}{l}\text { Cement } \\
\text { Type }\end{array}$ & $\begin{array}{l}\text { Unit Weight } \\
\text { of Cement } \\
\left(\mathrm{kg} / \mathrm{m}^{3}\right)\end{array}$ & $\begin{array}{l}\text { Chemical } \\
\text { Admixture }\end{array}$ & $\begin{array}{c}\text { Curing } \\
\text { Temperature } \\
\left({ }^{\circ} \mathrm{C}\right)\end{array}$ & Evaluation Item \\
\hline \multirow{2}{*}{ I } & $330 \mathrm{P}$ & 0.50 & OPC & 330 & \multirow{2}{*}{ PC } & \multirow{2}{*}{$\begin{array}{c}\text { Chamber } \\
\left(13^{\circ} \mathrm{C}\right)\end{array}$} & - Slump (mm) \\
\hline & $380 \mathrm{P}$ & 0.43 & & 380 & & & - Compressive strength (MPa) \\
\hline \multirow{3}{*}{ II } & $330 \mathrm{P}$ & \multirow{3}{*}{0.50} & OPC & 330 & $P C^{(1)}$ & \multirow{3}{*}{$\begin{array}{l}\text { Room Temp. } \\
\quad\left(20^{\circ} \mathrm{C}\right)\end{array}$} & - Cylinder Mold $(\varnothing 100 \times 200)$ \\
\hline & 330HFS & & HFS & 330 & PC & & $-18,24$, and $72 \mathrm{~h}$ \\
\hline & $330 \mathrm{EP}$ & & EPC & 330 & PC & & and Maturity (D.h) \\
\hline
\end{tabular}

(1) PC: Polycarboxylic superplasticizer-based type admixture. ${ }^{(2)}$ ePC: early Polycarboxylic superplasticizer with triethanolamine (TEA).

In addition, HFS_OPC and EPC, which increased the fineness and $\mathrm{SO}_{3}$ content of cement, were additionally selected and examined to improve concrete strength considering the economic efficiency of concrete mixtures. For such concrete mixtures, the unit weight of cement was set as $330 \mathrm{~kg} / \mathrm{m}^{2}$, 
similar to that of C24. HFS (330P) increased the fineness and $\mathrm{SO}_{3}$ content of $\mathrm{OPC}$, and it is effective in developing the early strength $[14,15]$. However, as it has limitations in developing the early strength of concrete, ePC (early polycarboxylic superplasticizer with TEA) was added to HFS [23].

To identify the effect of the curing temperature on concrete strength, chamber $\left(13^{\circ} \mathrm{C}\right)$ and water curing $\left(20^{\circ} \mathrm{C}\right)$ were examined.

The slump (mm) and air content (\%) of concrete were evaluated to ensure that they could be used onsite. As for hardened properties, a cylindrical mold $(\varnothing 100 \mathrm{~mm} \times 200 \mathrm{~mm})$ was fabricated, and its concrete strength was measured at $18 \mathrm{~h}, 24 \mathrm{~h}$, and $72 \mathrm{~h}$. In addition, the temperature history $\left({ }^{\circ} \mathrm{C}\right)$ was measured, and the maturity (D.h) was calculated based on the temperature history. The time required to remove the vertical formwork on concrete was estimated at the curing temperature by examining the correlation between the concrete strength and maturity.

The formwork removal time on concrete is specified in each country's regulations. However, its decision criteria differ. This study referred to the Asian (including South Korea and Japan) criteria that present a detailed demolding strength value $[24,25]$. The strength criterion for the formwork removal of concrete was set as $5 \mathrm{MPa}$.

Table 3 shows the mixing proportions on concrete. For the mixing proportions on concrete, their corresponding practical values were used as reference, and the unit weight of water was $165 \mathrm{~kg} / \mathrm{m}^{2}$.

Table 3. Mixing proportions on concrete.

\begin{tabular}{|c|c|c|c|c|c|c|c|c|c|c|c|}
\hline \multirow{2}{*}{ Series } & \multirow{2}{*}{$\begin{array}{l}\text { Mix } \\
\text { ID. }\end{array}$} & \multirow{2}{*}{$\underset{\text { (1) }}{\text { W/C }}$} & \multirow{2}{*}{$\begin{array}{c}\text { S/a (2) } \\
(\%)\end{array}$} & \multicolumn{6}{|c|}{ Unit Weight $\left(\mathrm{kg} / \mathrm{m}^{3}\right)$} & \multirow{2}{*}{$\begin{array}{c}\text { PC } \\
(\mathbf{B} \times \%)\end{array}$} & \multirow{2}{*}{$\begin{array}{c}\mathrm{ePC} \\
(\mathrm{B} \times \%)\end{array}$} \\
\hline & & & & $W^{(3)}$ & $\mathrm{C}^{(4)}$ & HFS ${ }^{(5)}$ & EPC $^{(6)}$ & $S^{(7)}$ & $\mathrm{G}^{(8)}$ & & \\
\hline \multirow{3}{*}{ I } & $330 \mathrm{P}$ & 0.50 & 48.5 & 165 & 330 & & & 885 & 891 & 0.8 & \\
\hline & $350 \mathrm{P}$ & 0.47 & 48.5 & 165 & 350 & & & 876 & 883 & 0.8 & \\
\hline & $380 \mathrm{P}$ & 0.43 & 48.5 & 165 & 380 & & & 864 & 870 & 0.8 & \\
\hline \multirow{4}{*}{ II } & $330 \mathrm{P}$ & 0.50 & 48.5 & 165 & 330 & & & 885 & 891 & 0.8 & \multirow{4}{*}{0.8} \\
\hline & $330 \mathrm{HFS}$ & 0.50 & 48.5 & 165 & & 330 & & 884 & 890 & 0.8 & \\
\hline & 330HFS_ePC & 0.50 & 48.5 & 165 & & 330 & & 884 & 890 & & \\
\hline & 330EP & 0.50 & 48.5 & 165 & & & 330 & 885 & 891 & 0.8 & \\
\hline
\end{tabular}

(1) W/C: Water/Cement; ${ }^{(2)}$ S/a: Sand/aggregates; ${ }^{(3)} \mathrm{W}$ : Water; ${ }^{(4)}$ Cement; ${ }^{(5)}$ High fineness and $\mathrm{SO}_{3}$ ordinary

Portland cement ${ }^{(6)}$ Early Portland cement; ${ }^{(7)}$ Sea sand + Crushed sand; ${ }^{(8)}$ G: Gravel.

For the fine aggregates, crushed sand and washed sea sand were mixed at a volume ratio of 6:4. For the fresh properties on concrete, the slump was set to $180 \pm 25 \mathrm{~mm}$ and air content was $4.5 \pm 1.5 \%$, respectively, to apply workability in the construction site.

The concretes were mixed using a commercial machine (mixing speed: 5-50 rpm, mixing capacity: $180 \mathrm{~L}$ double-axial spiral mixing type, Woojin, Korea). The fine aggregate was added and mixed for 30 $\mathrm{s}$. Then, the binder, water, and coarse aggregate were added and mixed for $30 \mathrm{~s}$. To ensure sufficient workability, a superplasticizer was added and mixed for $30 \mathrm{~s}$. The concrete mix was prepared in $150 \mathrm{~s}$.

\subsection{Test Methods}

\subsubsection{Properties of Raw Materials and Concrete}

Table 4 shows the test methods for properties of the raw materials and concrete. This study attempted to examine the effects of the unit weight of cement and factors related to the cement types on concrete strength development of concrete. The raw material analysis of cement was conducted to investigate the physicochemical properties of cement. Experiments were performed in accordance with ASTM C204 [26] for the particle size distribution of cement, ASTM C114 [27] for XRF, and ASTM C1702 [28] for the heat of hydration. 
Table 4. Test methods for engineering properties of raw materials and concrete.

\begin{tabular}{ccc}
\hline Series & Test Item & Test Method \\
\hline Raw materials & Particle size distribution $(\%)$ & ASTM C204 \\
(Cement) & X-ray fluorescence & ASTM C114 \\
& Heat of Hydration & ASTM C1702 \\
Mechanical properties analysis & Compressive strength (MPa) & ASTM C873 \\
(Concrete) & Maturity $(\mathrm{D} \cdot \mathrm{h})$ & ASTM C39 \\
& & ASTM C1074 \\
\hline
\end{tabular}

The slump of fresh concrete was evaluated according to ASTM C143/C143M [29], and the air content test method was evaluated according to ASTM C231/C231M-17a [30]. To secure the workability of concrete that arrived at the site, the fresh properties of concrete were evaluated after $60 \mathrm{~min}$. Specimens for compressive strength test were fabricated with dimensions of $\varnothing 100 \mathrm{~mm} \times 200 \mathrm{~mm}$. The specimens were cured at $13{ }^{\circ} \mathrm{C}$ and $20^{\circ} \mathrm{C}$ using a constant temperature and humidity chamber.

The compressive strength of the concrete was calculated after measuring the maximum load using a 300-ton class universal test machine in accordance with ASTM C873 [31] and ASTM C39/C39M [32] at the ages of $18 \mathrm{~h}, 24 \mathrm{~h}$, and $72 \mathrm{~h}$.

\subsubsection{Temperature History and Maturity on Concrete}

To obtain the temperature history of concrete, the hydration history was measured by embedding $\mathrm{K}$-type thermocouples at the center of concrete specimen. The maturity was calculated as follows in accordance with ASTM C1074 [33]:

$$
M(t)=\sum\left(T_{a}-T_{0}\right) \Delta t
$$

where $M(t)=$ the temperature-time factor at age $t$ (degree-days or degree-h), $\Delta t=$ time interval (days or $\mathrm{h}), T_{a}=$ average concrete temperature during time interval $\left(\Delta t,{ }^{\circ} \mathrm{C}\right)$, and $T_{0}=$ datum temperature $\left({ }^{\circ} \mathrm{C}\right)$.

\section{Results and Discussion}

\subsection{Fresh and Hardened Properties on Concrete}

Table 5 shows the fresh properties on concrete. When all the concrete mixtures were evaluated, the slump could meet the target range of $180 \pm 25 \mathrm{~mm}$ both at the beginning and after $60 \mathrm{~min}$. The air content of concrete met range of $4.5 \pm 1.5 \%$ for all the mixtures, and its reduction was not significant even after $60 \mathrm{~min}$.

Table 5. Fresh properties on concrete.

\begin{tabular}{ccccc}
\hline \multirow{2}{*}{ Mix ID. } & \multicolumn{2}{c}{ Slump $\mathbf{( m m )}$} & \multicolumn{2}{c}{ Air Content (\%) } \\
\cline { 2 - 5 } & Initial & After $\mathbf{6 0}$ min. & Initial & After $\mathbf{6 0}$ min. \\
\hline 330P & 190 & 175 & 5.4 & 5.0 \\
350P & 195 & 185 & 4.8 & 4.4 \\
380P & 195 & 180 & 4.3 & 3.9 \\
330HFS & 200 & 185 & 4.4 & 4.0 \\
330HFS_ePC & 205 & 190 & 5.8 & 5.4 \\
330EP & 195 & 175 & 5.5 & 5.0 \\
\hline
\end{tabular}

Figure 2 shows the concrete strength at early age. As for the concrete strength that used OPC according to the unit weight of cement, no difference between the strength developments of 330P and $350 \mathrm{P}$ was reported. For $380 \mathrm{P}$, the strength continuously increased even at $13^{\circ} \mathrm{C}$. At $20^{\circ} \mathrm{C}$, the concrete strength rate was found to be similar for all the specimens until $24 \mathrm{~h}$. However, 380P showed a higher 
strength development after $72 \mathrm{~h}$. In addition, for the concrete mixtures that used OPC, a compressive strength of $5 \mathrm{MPa}$ was developed after $24 \mathrm{~h}$ and $72 \mathrm{~h}$ in the case of $20^{\circ} \mathrm{C}$ and $13{ }^{\circ} \mathrm{C}$, especially.

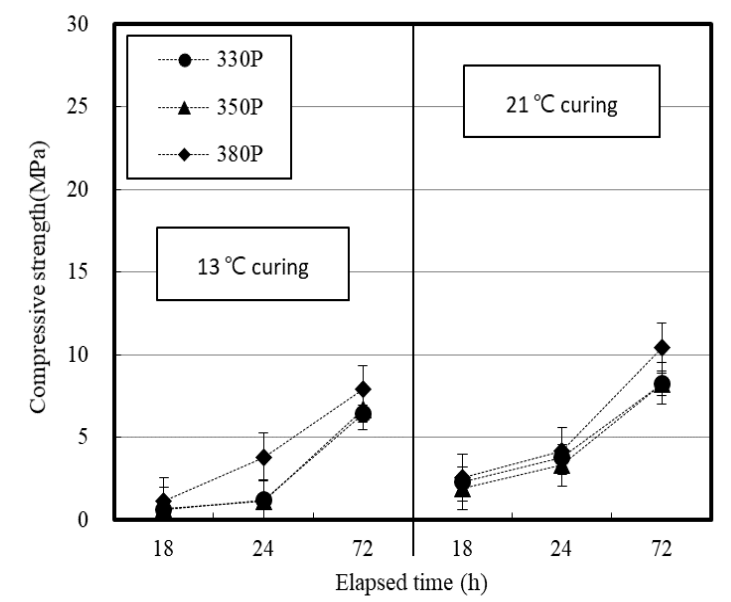

(a)

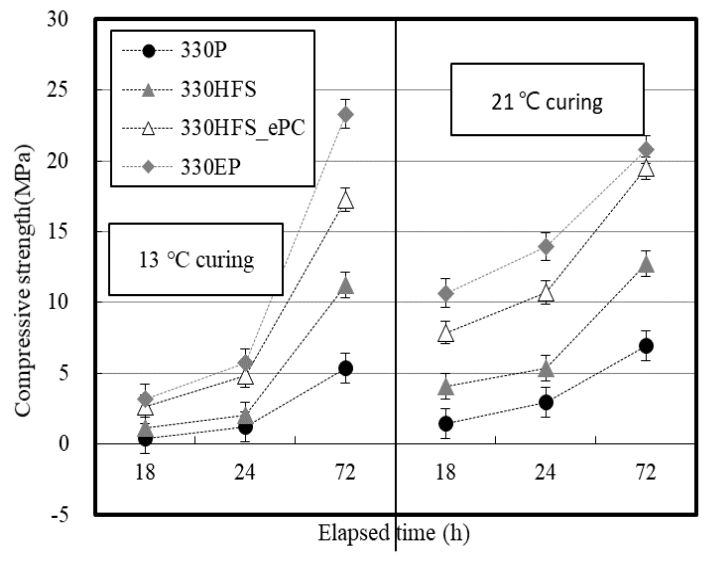

(b)

Figure 2. Concrete strength development at early age: (a) Cement amount and (b) cement type and chemical admixture.

For 330HFS, the concrete strength was slightly higher compared to OPC until $24 \mathrm{~h}$. However, it significantly increased and exceeded $10 \mathrm{MPa}$ at $72 \mathrm{~h}$ under the curing condition at $13{ }^{\circ} \mathrm{C}$. For 330HFS_EPC, the compressive strength was $2.7 \mathrm{MPa}$ at $18 \mathrm{~h}$ and close to $5 \mathrm{MPa}$ at $24 \mathrm{~h}$. It increased with a slope similar to that of 330HFS at $72 \mathrm{~h}$, thereby exhibiting very high strength development compared to 330P. 330EP exhibited a difference in strength development of less than $1 \mathrm{MPa}$ compared to 330HFS_ePC, but showed a significantly higher compressive strength increase rate at $72 \mathrm{~h}$.

At the $20^{\circ} \mathrm{C}$ curing temperature, concrete exhibited a higher strength development rate than that at $13{ }^{\circ} \mathrm{C}$. For 330EP and 330HFS_ePC, the compressive strength reached $5 \mathrm{MPa}$ within $18 \mathrm{~h}$, and this value was reached within $24 \mathrm{~h}$ for 330HFS and in the $24-72 \mathrm{~h}$ range for 330P. 330P_ePC reached $5 \mathrm{MPa}$ within $24 \mathrm{~h}$ at $13^{\circ} \mathrm{C}$, and the effect was significantly increased at a higher curing temperature.

\subsection{Temperature History and Maturity on Concrete}

Figure 3 shows the maturity of concrete according to the elapsed time. When a chamber with a constant temperature and humidity is used, the temperature changes within the $\pm 2{ }^{\circ} \mathrm{C}$ range at the set temperatures of $13^{\circ} \mathrm{C}$ and $20^{\circ} \mathrm{C}$. In this study, the maturity was calculated as the average chamber curing temperature because the error range of $\pm 2{ }^{\circ} \mathrm{C}$ was met, although there were some differences depending on the concrete mixture. The maturity of concrete linearly increased, which exhibited higher values at a $20^{\circ} \mathrm{C}$ compared to $13^{\circ} \mathrm{C}$, and this difference significantly increased over time.

Figure 4 shows the relation between the maturity and concrete strength at early ages. For the specimens that used OPC in which the unit weight of cement was increased, the compressive strength development tended to increase according to the maturity, but its effect was not significant. The maturity to develop $5 \mathrm{MPa}$ was $1375 \mathrm{D} \cdot \mathrm{h}(330 \mathrm{P}), 1108 \mathrm{D} \cdot \mathrm{h}(350 \mathrm{P})$, and $827 \mathrm{D} \cdot \mathrm{h}(380 \mathrm{P})$. For 380P in which the unit weight of cement was increased, the maturity value to develop $5 \mathrm{MPa}$ was approximately $60 \%$ that of 330P. 


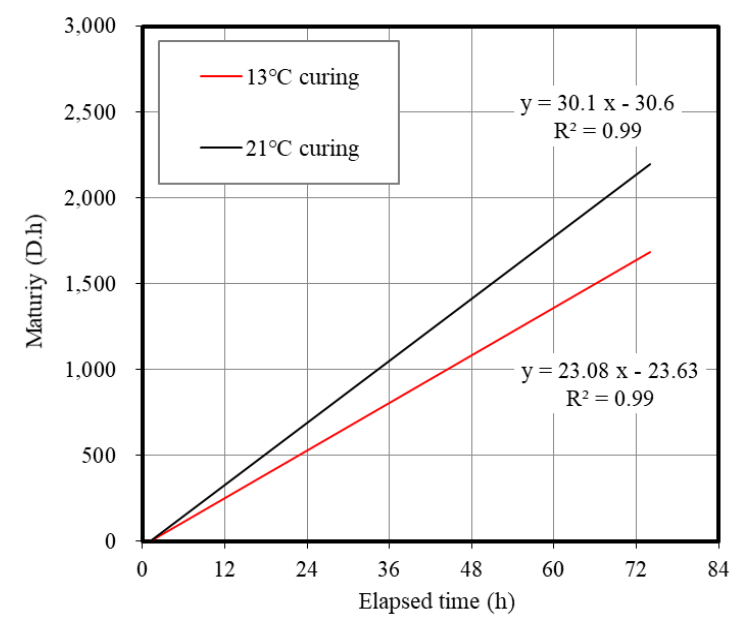

Figure 3. Maturity of concrete according to the elapsed time.

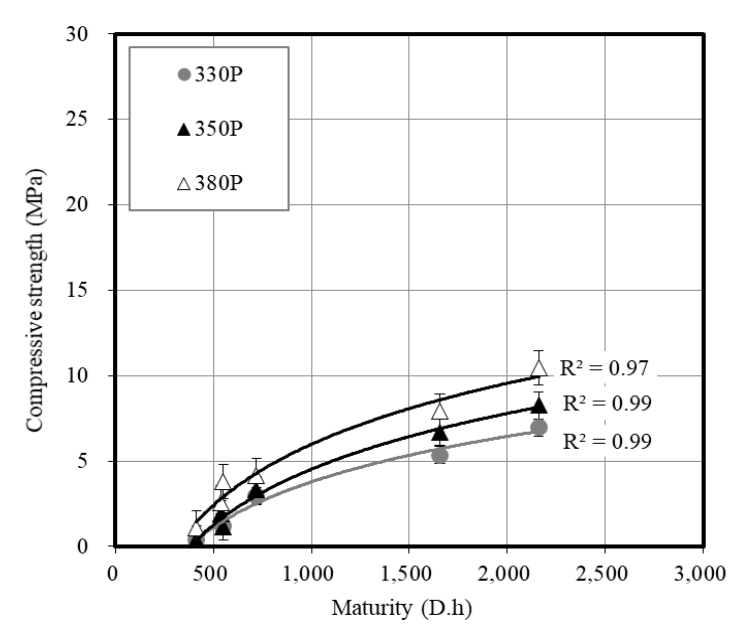

(a)

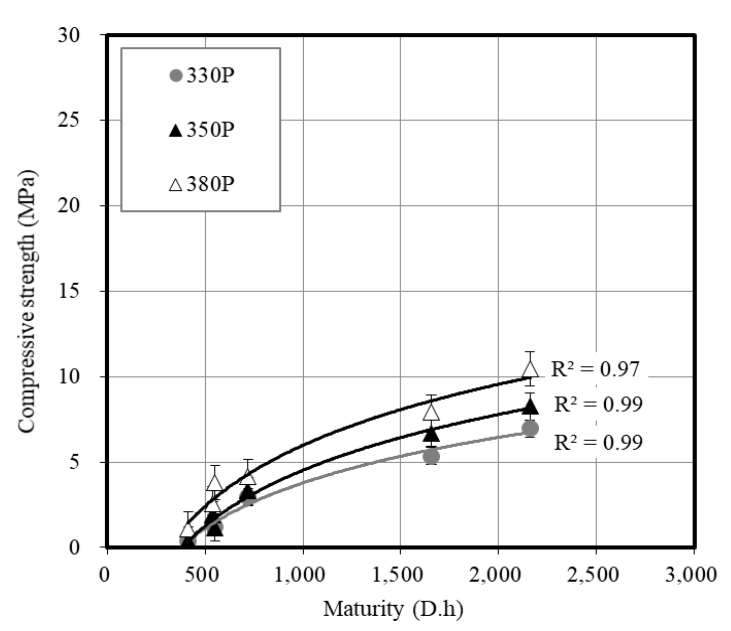

(b)

Figure 4. Relation between maturity and concrete strength at early ages: (a) Cement amount and (b) cement type and chemical admixture.

The compressive strength of each cement type significantly increased with the maturity. The maturity to develop $5 \mathrm{MPa}$ was $708 \mathrm{D} \cdot \mathrm{h}$ for 330HFS and $408 \mathrm{D} \cdot \mathrm{h}$ for 330EP. It was $475 \mathrm{D} \cdot \mathrm{h}$ for 330HFS_ePC, which was almost similar to the value of 330EP. For 330HFS, the maturity to develop $5 \mathrm{MPa}$ was also approximately $50 \%$ that of $330 \mathrm{P}$, which was lower than the value of $380 \mathrm{P}$. This indicates that using HFS or EPC is more efficient than increasing the unit weight of cement to secure the concrete strength.

\subsection{Effect of Cement Fineness on Concrete Early Strength}

Figure 5 shows the particle size distribution of OPC, HFS, and EPC. The volume was found to be in the following order when the particle size distribution of each cement type was analyzed: OPC (mean size: $16.49 \mu \mathrm{m}$; fineness: $330 \mathrm{~m}^{2} / \mathrm{kg}$ ) < HFS (mean size: $16.31 \mu \mathrm{m}$; fineness: $380 \mathrm{~m}^{2} / \mathrm{kg}$ ) < EPC (mean size: $14.01 \mu \mathrm{m}$; fineness: $488 \mathrm{~m}^{2} / \mathrm{kg}$ ). 


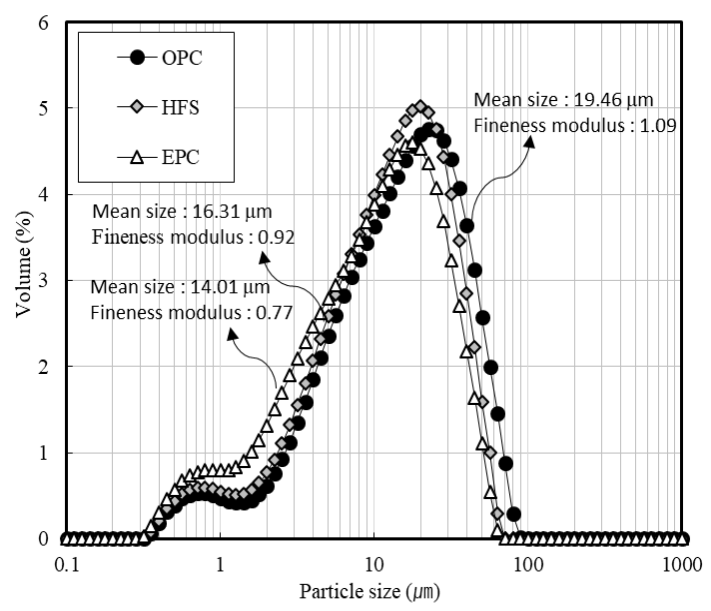

Figure 5. Particle size distribution of ordinary Portland cement (OPC), high fineness and $\mathrm{SO}_{3}$ ordinary Portland cement (HSPC), and early Portland cement (EPC).

Figure 6 shows the relation of fineness of cement and concrete strength. The relative strength of concrete was calculated as follows:

$$
\text { Relative strength }=\frac{f_{c u}}{f_{330 p}}
$$

where $f_{c u}=$ compressive strength with mixture and $f_{330 \mathrm{p}}=$ compressive strength of 330p.

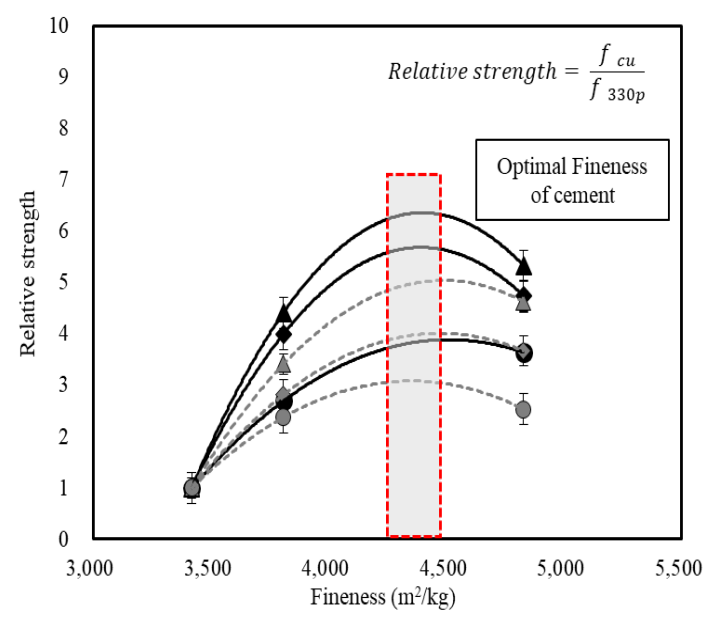

Figure 6. Relation between fineness of cement and compressive strength development.

The relation between the fineness of cement and concrete strength showed that the compressive strength tended to increase with the fineness of cement. The optimal fineness, however, was found to be between $4300 \mathrm{~m}^{2} / \mathrm{kg}$ and $4500 \mathrm{~m}^{2} / \mathrm{kg}$. In addition, the high fineness of cement had a higher effect on the concrete strength at low temperatures.

In particular, when $330 \mathrm{HFS}$ was used, the strength was approximately twice that of $330 \mathrm{P}$ at $13^{\circ} \mathrm{C}$, and this effect was higher at early ages, i.e., less than $24 \mathrm{~h}$. Although 330HFS was found to be favorable for applying the concrete strength of $5 \mathrm{MPa}$, its strength development was found to be slightly lower than that of $330 \mathrm{EP}$ after $24 \mathrm{~h}$. At temperatures higher than $20^{\circ} \mathrm{C}$, the relative strength increased with the fineness of cement in a manner similar to that of the $13^{\circ} \mathrm{C}$ curing.

This difference in fineness is significantly related to the hydration reaction of cement. Figure 7 shows the variation in heat of microhydration with elapsed time for each cement type. HFS and EPC had higher microhydration heat values than OPC at early ages less than $24 \mathrm{~h}$. Figure 8 shows the 
cumulative heat of microhydration for each cement type. The plot of the cumulative microhydration heat of cement also shows that HFS and EPC exhibited values more than twice higher than those of OPC from the point of contact with water. Based on this, the total amount of heat of each mixture can be calculated according to the unit weight of cement.

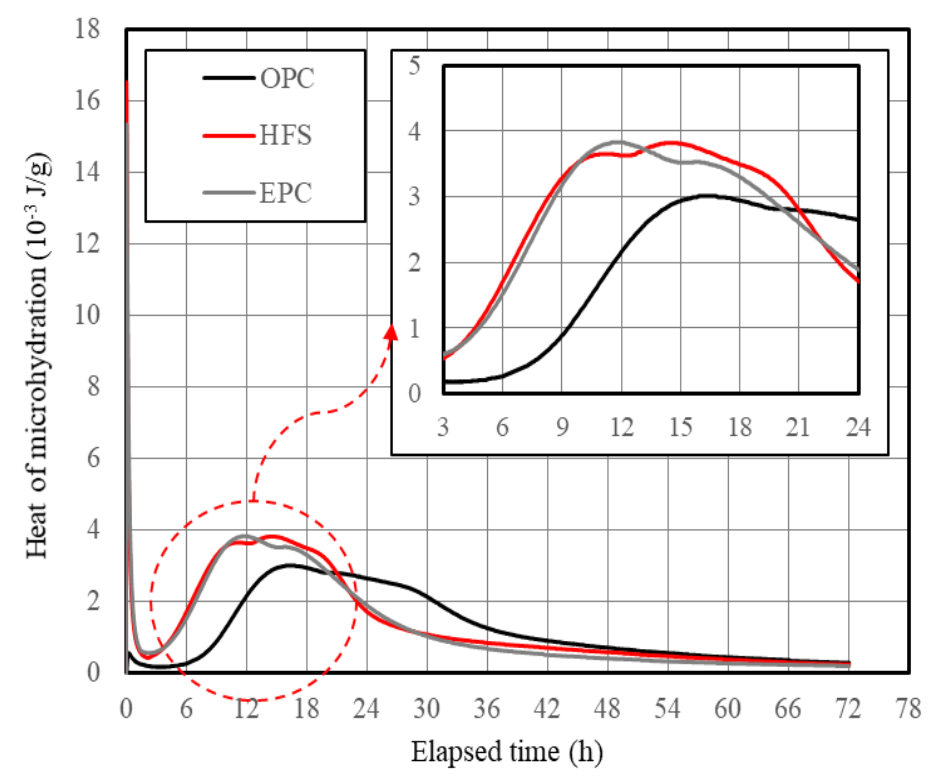

Figure 7. Heat of microhydration according to elapsed time for each cement type.

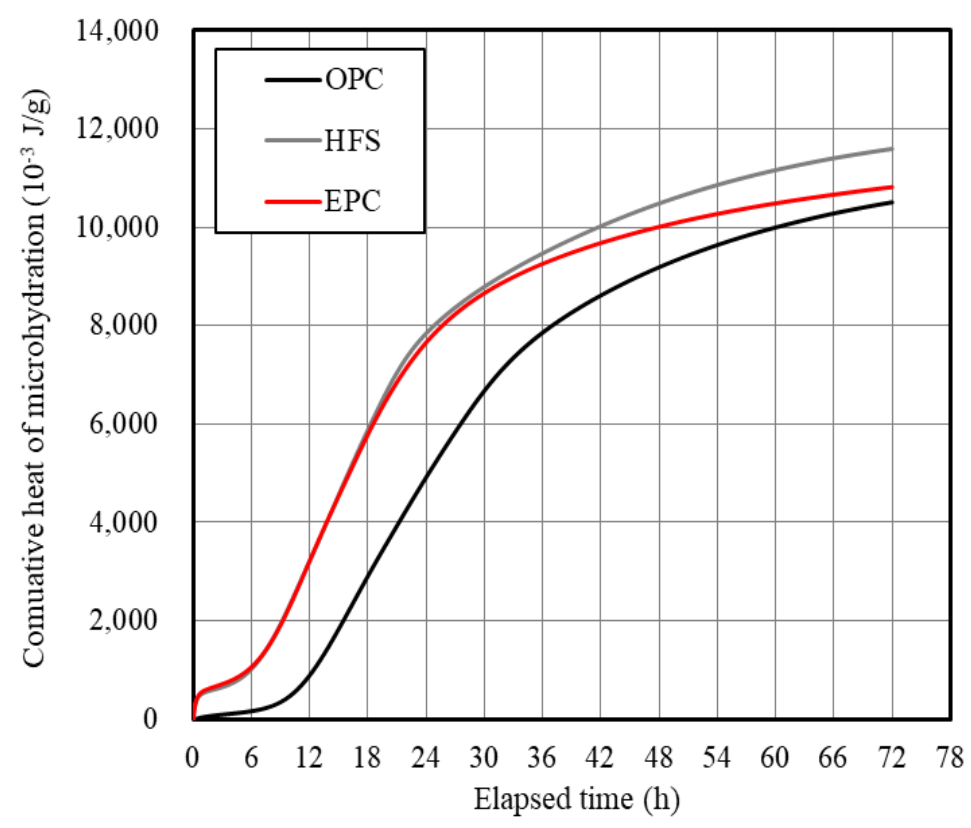

Figure 8. Cumulative microhydration heat according to the cement type.

There was no significant difference in the total amount of heat according to the unit weight of cement within $24 \mathrm{~h}$, which was also related to the maturity and compressive strength results (see Figure 4a). In addition, after $24 \mathrm{~h}$, the amount of heat significantly increased as the unit weight of cement increased, indicating that the unit weight of cement affects the concrete strength. Figure 9 shows the variation in the cumulative microhydration heat according to the cement type. 


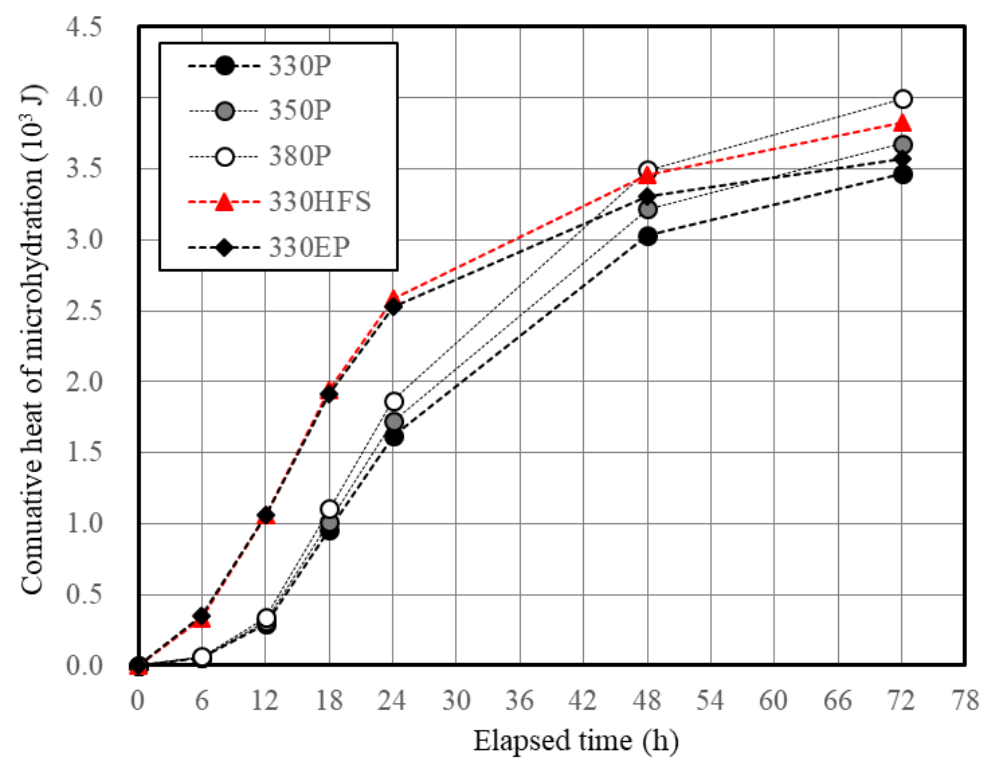

Figure 9. Variation in cumulative heat of microhydration according to each cement.

In addition, the results of analyzing the amount of heat according to the cement type showed that HFS and EPC exhibited similar values until $24 \mathrm{~h}$, but the amount of heat from EPC tended to decrease after $24 \mathrm{~h}$. In general, for concrete that uses EPC, fast early strength development is secured but the long-term strength tends to decrease $[9,10]$.

\subsection{Effect of Cement $\mathrm{SO}_{3}$ Contents on Concrete Early Strength}

Figure 10 shows the XRF analysis results of OPC, HFS, and EPC cements. The $\mathrm{SO}_{3}$ contents of HFS and EPC were observed to be higher than 3\%. They were approximately $107-129 \%$ higher than value of OPC. The $\mathrm{SO}_{3} / \mathrm{Al}_{2} \mathrm{O}_{3}$ value that represents the early strength performance of concrete was $116.1 \%$ higher for HFS and $132.2 \%$ higher for EPC than that of OPC.

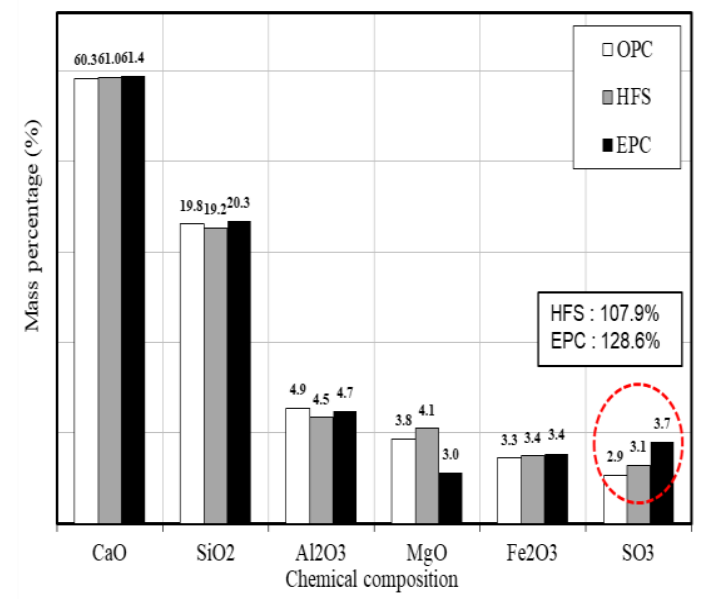

Figure 10. X-ray fluorescence (XRF) analysis results of OPC, HSPC, and EPC.

Figure 11 shows the relation between the $\mathrm{SO}_{3}$ contents of cement and compressive strength development, which was found to be linear. ASTM C150 [8] limits the $\mathrm{SO}_{3}$ content of Portland cement to $3.5 \%$ and suggests an optimal $\mathrm{SO}_{3}$ content of 3.1\%. In addition, EN 197-1 [34] limits the $\mathrm{SO}_{3}$ content to $4.0 \%$. The relative strength obtained in this study, unlike that of 330P, linearly increased with the $\mathrm{SO}_{3}$ content in the range smaller than EN 197-1. In addition, the effect on the relative strength was higher 
at the lower temperature of $13{ }^{\circ} \mathrm{C}$. The relative strength of 380P appears to have increased because the overall $\mathrm{SO}_{3}$ content increased owing to the increase in the unit weight of cement.

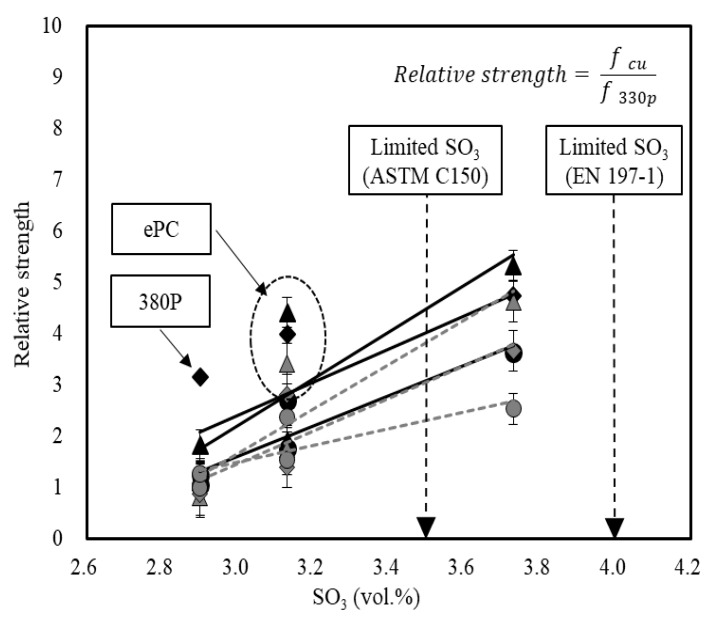

Figure 11. Relation between $\mathrm{SO}_{3}$ contents of cement and compressive strength development.

In the case of EPC with high fineness, the compressive strength increased after $24 \mathrm{~h}$ despite the reduction in the microhydration heat because the high $\mathrm{SO}_{3}$ content contributed to the strength improvement $[2,8]$. The relative strength of HFS tended to be higher than value of OPC with the higher cement fineness and $\mathrm{SO}_{3}$ content. When EPC was used, the effect was increased by approximately $1.5-2$ times.

Mohammed and Safiullah [35] and Lee and Lee [14,15] reported that the compressive strength significantly increased after $48 \mathrm{~h}$ when the $\mathrm{SO}_{3}$ content was between $3.0 \%$ and $3.2 \%$. They also mentioned that increasing the fineness of cement (for which the $\mathrm{SO}_{3}$ content was increased to $3.1 \%$ here) had a large impact on the early strength. In this study, when EPC was additionally used in the $\mathrm{SO}_{3}$ content range of less than $4 \%$, a strength development similar to the level of concrete using EPC was achievable.

\subsection{Comparison of Escape Time for Vetical Form Removal}

Figure 12 shows the variation in concrete strength according to the average temperature after $12 \mathrm{~h}$. Based on the relationship between the maturity and concrete strength, concrete strength development after $12 \mathrm{~h}$ of curing time was calculated and reviewed by referring to the codes of each country [36]. This was conducted to derive the optimal mixture by establishing an objective criterion for the formwork removal time of concrete.

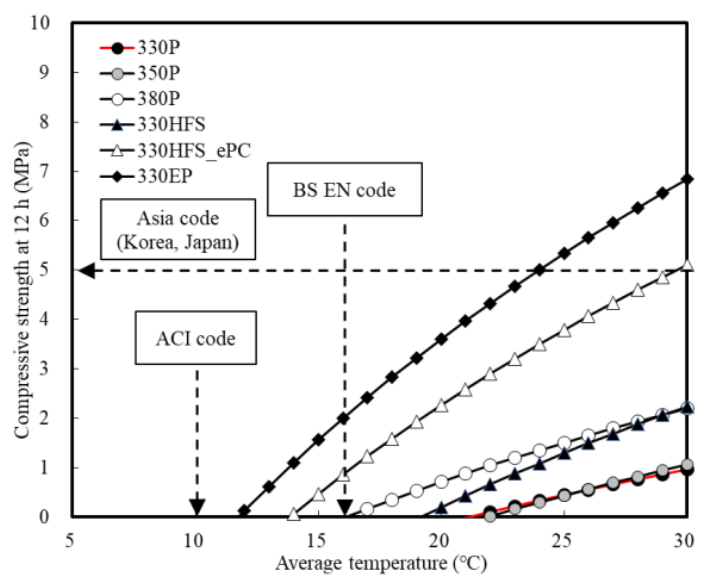

Figure 12. Variation in the concrete the strength according to the average temperature after $12 \mathrm{~h}$. 
The results of this study showed that it would be difficult to apply the $10{ }^{\circ} \mathrm{C}$ and $12 \mathrm{~h}$ demolding conditions suggested by American Concrete Institute (ACI) [20] because compressive strength development was not observed in all the mixtures. Further, the application of British Standards (BS) EN [22] is difficult except for 330EP and 330HFS_ePC.

The Asian (South Korea and Japan) criterion of $5 \mathrm{MPa}[23,24]$ was found to be applicable only to 330EP and 330HFS_ePC at $12 \mathrm{~h}$. As the accurate value for demolding strength was presented, however, it is expected that the formwork removal time can be predicted by examining the compressive strength and applying the maturity. Therefore, in this study, the demolding strength of each mixture was analyzed using the Asian criterion, as aforementioned.

Figure 13 shows the variation in the elapsed time at the strength of $5 \mathrm{MPa}$ for concrete. The $5 \mathrm{MPa}$ development time was examined according to the $10^{\circ} \mathrm{C}$ condition suggested by $\mathrm{ACI}$ and the $20^{\circ} \mathrm{C}$ condition, which is the curing criterion managed in the field. An order of 330P $(68 \mathrm{~h})>350 \mathrm{P}(55 \mathrm{~h})<$ 380P $(41 \mathrm{~h})<330$ HFS $(35 \mathrm{~h})<330$ HFS_ePC $(24 \mathrm{~h})<330 \mathrm{EP}(20 \mathrm{~h})$ was found at $10^{\circ} \mathrm{C}$. At $20^{\circ} \mathrm{C}$, the following order was found: 330P $(46 \mathrm{~h})>350 \mathrm{P}(37 \mathrm{~h})<380 \mathrm{P}(28 \mathrm{~h})<330$ HFS $(24 \mathrm{~h})<330$ HFS_ePC $(16 \mathrm{~h})<330 \mathrm{EP}(14 \mathrm{~h})$. The formwork removal time was shortened as the temperature increased, and 330HFS_ePC and 330EP exhibited almost similar formwork removal times.

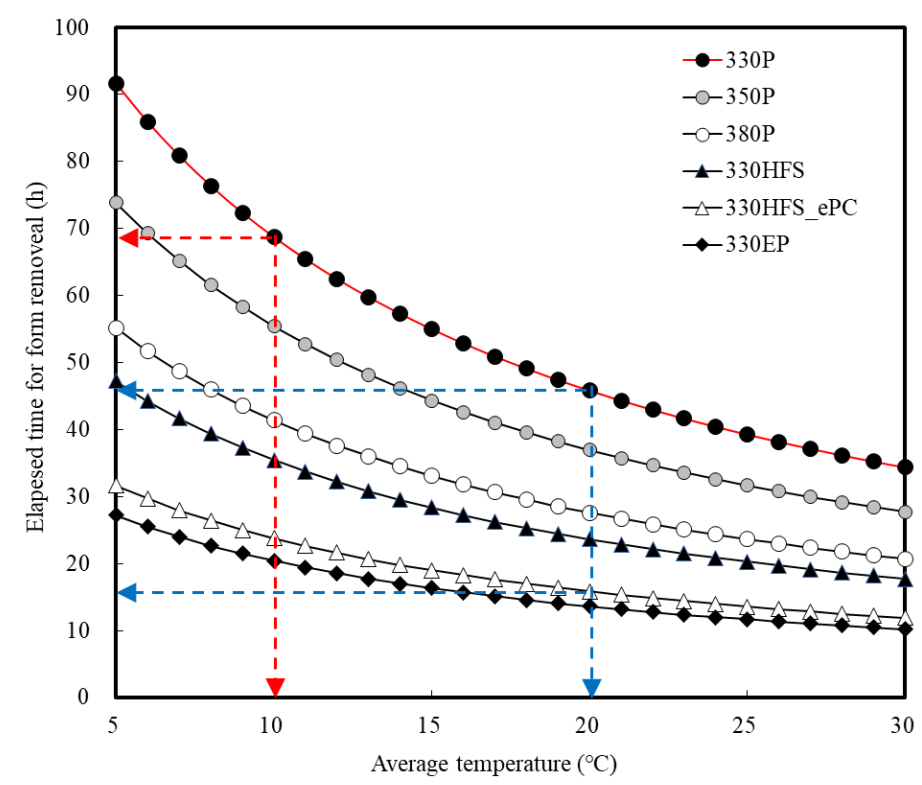

Figure 13. Variation in the elapsed time at strength of $5 \mathrm{MPa}$ for concrete.

Further, future studies should be conducted on securing the demolding time of the formwork using environmentally friendly materials $[37,38]$ and the corrosion resistance according to the $\mathrm{SO}_{3}$ content [39].

\section{Conclusions}

This study evaluated the effects of the unit weight of cement on concrete that uses OPC on early strength development. HFS_OPC and EPC were selected, and the effects of cement fineness, $\mathrm{SO}_{3}$ content, and chemical admixture were analyzed. The results are summarized as follows.

(1) The slump and air content necessary for securing the workability on concrete met the set target ranges both at the beginning and after $60 \mathrm{~min}$. The strength development of concrete was further accelerated by the cement type and the addition of EPC than when the unit weight of cement was increased. In addition, the strength development rate of concrete was higher at lower temperatures. 
(2) For the maturity of concrete, the strength development tended to increase according to the maturity. This is because the unit weight of cement increased for the concrete mixtures that used OPC. The effect, however, was not significant when the HFS_OPC and EPC were used.

(3) When the amount of heat of each mixture was calculated based on the microhydration heat results of cement, no significant differences were found in the total amount of heat within $24 \mathrm{~h}$ depending on the unit weight of cement. In addition, analyzing the results of the amount of heat for each cement type showed that HFS and EPC exhibited significantly high values compared to OPC until $24 \mathrm{~h}$, indicating that they are favorable for the development of early strength.

(4) The relation between concrete strength and the cement fineness showed that the compressive strength tended to increase with the fineness of cement, and an optimal fineness between $4300 \mathrm{~m}^{2} / \mathrm{kg}$ and $4500 \mathrm{~m}^{2} / \mathrm{kg}$ was obtained. The microhydration heat was found to be higher when the fineness of cement was high than when the unit weight of cement was increased. The results of analyzing the amount of heat for each cement type showed that HFS and EPC exhibited significantly higher values compared with OPC up to $24 \mathrm{~h}$. Thus, they are expected to be favorable for early strength development.

(5) A linear relationship was observed between the $\mathrm{SO}_{3}$ content and relative strength of cement when $\mathrm{SO}_{3}$ content was less than $4 \%$. In addition, when the unit weight of cement was increased, the early strength was slightly increased owing to the increase in overall $\mathrm{SO}_{3}$ content.

(6) The criterion of each country for the formwork removal time on concrete were examined and applying the Asian criterion was judged to be effective, which presents a clear compressive strength of $5 \mathrm{MPa}$. The use of EPC and HFS_ePC can shorten the formwork removal time by $20-24 \mathrm{~h}$ at $10{ }^{\circ} \mathrm{C}$ and by $14-16 \mathrm{~h}$ at $20^{\circ} \mathrm{C}$.

Author Contributions: Conceptualization, T.L., J.L., and H.C.; methodology, T.L., J.L., and H.C.; investigation, T.L., J.L., J.K., H.C. and D.-E.L.; resources, T.L. and J.L.; writing-original draft preparation, T.L. and J.L.; writing-review and editing, T.L., J.L., J.K., H.C and D.-E.L. All authors have read and agreed to the published version of the manuscript.

Funding: This research was supported by the National Research Foundation of Korea (NRF) grant funded by the Korea government (MSIT), grant number NRF-2018R1A5A1025137.

Conflicts of Interest: The authors declare no conflict of interest.

\section{References}

1. Barnes, P.; Bensted, J. Structure and Performance of Cements, 2nd ed.; CRC Press: London, UK, 2002. [CrossRef]

2. Mehta, P.; Monteiro, P. Concrete: Microstructure, Properties, and Materials, 3rd ed.; McGraw-Hill: New York, NY, USA, 2006.

3. Scrivener, K.L.; Nonat, A. Hydration of cementitious materials, present and future. Cem. Concr. Res. 2011, 41, 651-665. [CrossRef]

4. Juilland, K.; Monteiro, P. Advances in understanding hydration of Portland cement. Cem. Concr. Res. 2015, 78, 38-56. [CrossRef]

5. Abrams, D. Design of Concrete Mixtures, Structural Materials Research Laboratory; Bulletin No. 1, PCA LS001; Lewis Institute: Chicago, IL, USA, 1919.

6. Cheung, J.; Jeknavorian, A.; Roberts, L.; Silva, D. Impact of admixtures on the hydration kinetics of Portland cement. Cem. Concr. Res. 2011, 41, 1289-1309. [CrossRef]

7. Bentz, D.P.; Peltz, M.; Winpigler, J. Early-age properties of cement-based materials: II. Influence of water-to-cement ratio. ASCE J. Mat. Civ. Eng. 2009, 1-14. [CrossRef]

8. ASTM C150. Standard specification for Portland cement. In American Society of Testing and Materials; ASTM: West Conshohocken, PA, USA, 2019; pp. 1-10.

9. Bentz, D.P. Blending different fineness cements to engineer the properties of cement-based materials. Mag. Concr. Res. 2010, 62, 327-338. [CrossRef]

10. Bentz, D.P.; Haecker, C.J. An argument for using coarse cements in high-performance concretes. Cem. Concr. Res. 1999, 29, 615-618. [CrossRef] 
11. Bentz, D.P.; Garboczi, E.J.; Haecker, C.J.; Jensen, O.M. Effects of cement particle size distribution on performance properties of Portland cement-based materials. Cem. Concr. Res. 1999, 29, 1663-1671. [CrossRef]

12. Frigione, G.; Marra, S. Relationship between particle size distribution and compressive strength in Portland cement. Cem. Concr. Res. 1976, 6, 113-127. [CrossRef]

13. Osbaeck, B.; Johansen, V. Particle size distribution and rate of strength development of Portland cement. J. Am. Ceram. Soc. 1989, 72, 197-201. [CrossRef]

14. Lee, J.; Lee, T. Influences of chemical composition and fineness on the development of concrete strength by curing conditions. Materials 2019, 12, 4061. [CrossRef] [PubMed]

15. Lee, J.; Lee, T. Effects of high CaO fly ash and sulfate activator as a finer binder for cementless grouting material. Materials 2019, 12, 3664. [CrossRef] [PubMed]

16. Rixon, R.; Mailvaganam, N. Chemical Admixtures for Concrete, 3rd ed.; E \& FN Spon: London, UK, 1999. [CrossRef]

17. Heren, Z; Ölmez, H. The influence of ethanolamines on the hydration and mechanical properties of Portland cement. Cem. Concr. Res. 1996, 26, 701-705. [CrossRef]

18. Aiad, I.; Mohammed, A.A.; Abo-El-Enein, S.A. Rheological properties of cement pastes admixed with some alkanolamines. Cem. Concr. Res. 2003, 33, 9-13. [CrossRef]

19. Aggoun, S.; Cheikh-Zouaoui, M.; Chikh, N.; Duval, R. Effect of some admixtures on the setting time and strength evolution of cement pastes at early ages. Constr. Build. Mater. 2008, 22, 106-110. [CrossRef]

20. ACI 347-04. Guide to Formwork for Concrete; ACI 347; ACI Committee: Farmington Hills, MI, USA, 2005.

21. Ceb-Fip Model code 1990, 1993: Design Code; Telford: London, UK, 1993. [CrossRef]

22. BS EN 13670:2009. Execution of Concrete Structures; BSI: London, UK, 2010.

23. KASS 5. Korea Architectural Standard Specification Reinforced Concrete Work; Architectural Institute of Korea: Seoul, Korea, 2009.

24. JASS 5. Japanese Architectural Standard Specification Reinforced Concrete Work; Architectural Institute of Japan: Tokyo, Japan, 2009.

25. Lee, T.; Lee, J.; Kim, Y. Effects of admixtures and accelerators on the development of concrete strength for horizontal form removal upon curing at $10^{\circ} \mathrm{C}$. Constr. Build. Mater. 2020, 37, 1-7. [CrossRef]

26. ASTM C204. Standard test methods for fineness of hydraulic cement by air-permeability apparatus. In American Society of Testing and Materials; ASTM: West Conshohocken, PA, USA, 2018; pp. 1-11.

27. ASTM C114-18. Standard test methods for chemical analysis of hydraulic cement. In American Society of Testing and Materials; ASTM: West Conshohocken, PA, USA, 2018; pp. 1-33.

28. ASTM C1702. Standard test method for measurement of heat of hydration of hydraulic cementitious materials using isothermal conduction calorimetry. In American Society of Testing and Materials; ASTM: West Conshohocken, PA, USA, 2015; pp. 1-9. [CrossRef]

29. ASTM C143/C143M REV A. Standard test method for slump of hydraulic-cement concrete. In American Society of Testing and Materials; ASTM: West Conshohocken, PA, USA, 2015; pp. 1-4.

30. ASTM C231/C231M-17a. Standard test method for air content of freshly mixed concrete by the pressure method. In American Society of Testing and Materials; ASTM: West Conshohocken, PA, USA, 2017; pp. 1-10.

31. ASTM C873/C873M. Standard test method for compressive strength of concrete cylinders cast in place in cylindrical molds. In American Society of Testing and Materials; ASTM: West Conshohocken, PA, USA, 2015; pp. 1-4. [CrossRef]

32. ASTM C39/C39M. Standard test method for compressive strength of cylindrical concrete specimens. In American Society of Testing and Materials; ASTM: West Conshohocken, PA, USA, 2018; pp. 1-8.

33. ASTM C1074. Standard practice for estimating concrete strength by the maturity method. In American Society of Testing and Materials; ASTM: West Conshohocken, PA, USA, 2019; pp. 1-10.

34. BS EN 197-1. Cement Part 1: Composition, Specifications and Conformity Criteria for Common; BSI: London, UK, 2011.

35. Mohammed, S.; Safiullah, O. Optimization of the $\mathrm{SO}_{3}$ content of an Algerian Portland cement: Study on the effect of various amounts of gypsum on cement properties. Constr. Build. Mater. 2018, 164, 362-370. [CrossRef]

36. Benaicha, M.; Burtschell, Y.; Alaoui, A. Prediction of compressive strength at early age of concrete-Application of maturity. J. Build. Eng. 2016, 6, 119-125. [CrossRef] 
37. Pomares, J.C.; Gonzalez, A.; Saura, P. Simple and Resistant Construction Built with Concrete Voussoirs for Developing Countries. J. Constr. Eng. Manag. 2018, 144. [CrossRef]

38. Bautista, A.; Pomares, J.C.; González, M.N.; Velasco, F. Influence of the microstructure of TMT reinforcing bars on their corrosion behavior in concrete with chlorides. Constr. Build. Mater. 2019, 229, 116899. [CrossRef]

39. Małek, M.; Jackowski, M.; Łasica, W.; Kadela, M. Characteristics of Recycled Polypropylene Fibers as an Addition to Concrete Fabrication Based on Portland Cement. Materials 2020, 13, 1827. [CrossRef] [PubMed]

(C) 2020 by the authors. Licensee MDPI, Basel, Switzerland. This article is an open access article distributed under the terms and conditions of the Creative Commons Attribution (CC BY) license (http://creativecommons.org/licenses/by/4.0/). 